\title{
Determining Rangeland Species Palatability: Application of Principal Component Analysis
}

\author{
By Valiollah Raufirad, Hossein Azadi, Ataollah Ebrahimi, and Setareh Bagheri
}

\section{On the Ground}

- Since plant palatability affects many aspects of sustainable rangeland management, including grazing capacity and grazing behavior, introducing indicators for determining rangeland species palatability can help rangeland managers determine rangeland species palatability accurately and precisely.

- The Karsanak rangelands in the Chaharmahal-VBakhtiari province in Iran are dominated by a mixture of patchily distributed grasses, forbs, and shrubs, with a high biodiversity of plants, which severely affects rangeland species palatability.

- The use of forage quality, secondary compounds, and external plant attributes are expected to help rangeland managers with plant palatability classification and in determining grazing capacity to achieve sustainable rangeland management.

Keywords: plant palatability, forage quality, secondary compounds, external plant attributes, principal component analysis, Karsanak rangelands.

Rangelands 38(3):105-112

doi 10.1016/..rala.2016.01.001

(c) 2016 The Society for Range Management

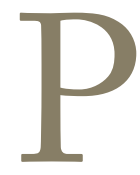

alatability is defined as plant characteristics or conditions that stimulate a selective response by animals. $^{1}$ It is also defined as an animal's preference for a particular plant. Plants vary in succulence, fiber content, nutrient and chemical contents, and morphologic features, such as spines or thorns. Palatability is based on the characteristics of a plant, such as chemical traits (nutrients, the amount of secondary compounds, etc.) and physical traits (hardness, trichome, etc.). ${ }^{2}$ Palatability is multifactorial because of the chemical and physical characteristics of the plant's tissues. ${ }^{3}$ Mkhize et al. believed that since these characteristics are likely to vary seasonally, palatability should not necessarily be regarded as a constant trait. ${ }^{3}$ Despite the interspecific differences in the seasonal patterns of palatability, Elger and Barrat-Seegretian stated that the rankings of species' palatability remain stable throughout the year ${ }^{4}$ and that feeding experiments performed on a single sampling date are suitable to assess the relative palatability of a set of species in aquatic habitats. However, most studies that investigated the palatability of perennial plants have not considered seasonal variability. ${ }^{3}$ Determining rangeland grazing capacity involves multiplying the amount of yield by allowable use or palatability to obtain the amount of forage available to grazing animals. If plant palatability is not determined accurately, the figure for grazing capacity will be incorrect, and this may cause overgrazing of pasture and, ultimately, rangeland degradation. ${ }^{5,6}$

Moreover, plant palatability affects the amount of plant coverage grazed by livestock, the preference value for each variety, competition between species, vegetation composition, and changes in plant communities. Palatability is also an important factor in evaluating and determining which animals (domestic and wild), and how many, should graze in a given pasture and in evaluating range condition. ${ }^{7}$ The most common way to determine a plant's palatability is to observe whether livestock eat the plant. However, the question as to what exact characteristics of a plant-including chemicals, nutrients, and morphologic characteristics - appeal to or repel livestock is crucial for determining the grazing capacity of a rangeland. ${ }^{1}$

\section{Factors Influencing Rangeland Species Palatability}

Many physical and chemical factors influence the palatability of plant species, of which chemical composition is considered the most important. High positive correlations with palatability were shown for protein content and carbohydrate aroma compounds and alkaloids, ${ }^{2,3}$ and high negative correlations have been shown between plant palatability and tanin content and organic acids. Other factors, such as the proportion of leaves, stems, and fruits, plant growth stages, past grazing use, 
climate, topography, soil moisture, and fertility, have been related to palatability mainly through their influence on chemical components. The external form of a plant, which is also a factor in palatability, is related to awns, spines, hairiness, and position of leaves, stickiness, and texture. 1,7

\section{Karsanak Rangelands}

The study area (Karsanak rangelands) is located near the village of Karsanak in Shahrekord city in Chaharmahal-VBakhtiari province ( $32^{\circ} 30^{\prime} 30^{\prime \prime} \mathrm{N}, 56^{\circ} 26^{\prime} 4^{\prime \prime} \mathrm{E}$ ) in Iran, at the elevation of over $2250 \mathrm{~m}$ sea level, which is in the semi-steppe ecologic zones (Fig. 1). The annual average temperature is $9.9^{\circ} \mathrm{C}$ and the average annual rainfall is $425 \mathrm{~mm}$ and lasts mainly from November to January. The vegetation area is dominated by a mixture of 21\% grasses, such as intermediate wheatgrass (Agropyron intermedium) and brome (Bromus tomentellus [Poaceae]; 11\% shrubs, mainly Persian manna (Astragalus adscendens), and gum dragon or tragacanth (Astragalus verus [Fabaceae]), and 68\% forbs, mainly Prangus acaulis and Prangus ferulacea [Umbelliferae]). The region's soil includes Cambisols, Leptosols, and Regosols. This region was selected because of centuries of grazing by domestic livestock under nomadic or semi-nomadic patterns of land use and a high biodiversity of plants, which severely affect rangeland species palatability. ${ }^{7}$

Palatability, in addition to being used for determining grazing capacity, is used to evaluate range condition and the selection of type, age composition, and animal ratio as well. However, despite the importance of determining species' palatability for rangeland management, not only in Iran but worldwide, no efforts have been made, to date, to introduce indicators, including both chemical and physical factors, for determining palatability. Because many factors interact in plant palatability and because determining some of them are time consuming or costly to measure, it is important to choose factors that are economical and give acceptable results. Our study evaluated the relationship between palatability and plants' morphologic and chemical characteristics to identify indicators that could determine rangeland species palatability.

The main objectives of our investigation were as follows:

1. Determine the species composition of the study area and the diet of the livestock grazing on the rangeland

2. Determine the external characteristics of the species dominated in the sampled livestock's diet (e.g., presence of awns, spines, hairiness, position of leaves, stickiness, texture, etc.)

3. Determine the forage quality of the species dominated including crude protein (CP), acid detergent fiber (ADF), dry-matter digestibility (DMD), and metabolism energy (ME)

4. Identify the secondary compounds of the extracted dominant species' essences by using gas chromatography-mass spectrometry (GC-MS)

5. Determine the relationship between palatability and plants' morphologic and chemical characteristics

\section{Vegetation Sampling}

We measured canopy cover, biomass, $\mathrm{CP}, \mathrm{ADF}, \mathrm{DMD}, \mathrm{ME}$, and secondary compounds in one shrub species, three grass species, and five forb species during June 2008 in the peak growing period for rangeland plants. We determined species composition by harvesting vegetation from 20 plots of $1 \mathrm{~m}^{2}$ each, distributed randomly at 50-m intervals along six transects of $400 \mathrm{~m}$ scattered throughout the study area for surveying species numbers, and by measuring plant cover and yield. Botanists identified the plants, dividing them into three functional groups: grasses, shrubs, and forbs. Finally, we classified the vegetation types and then evaluated canopy cover and forage yield for each species. The species (floristic) list of the sampled plants shows that the vegetation

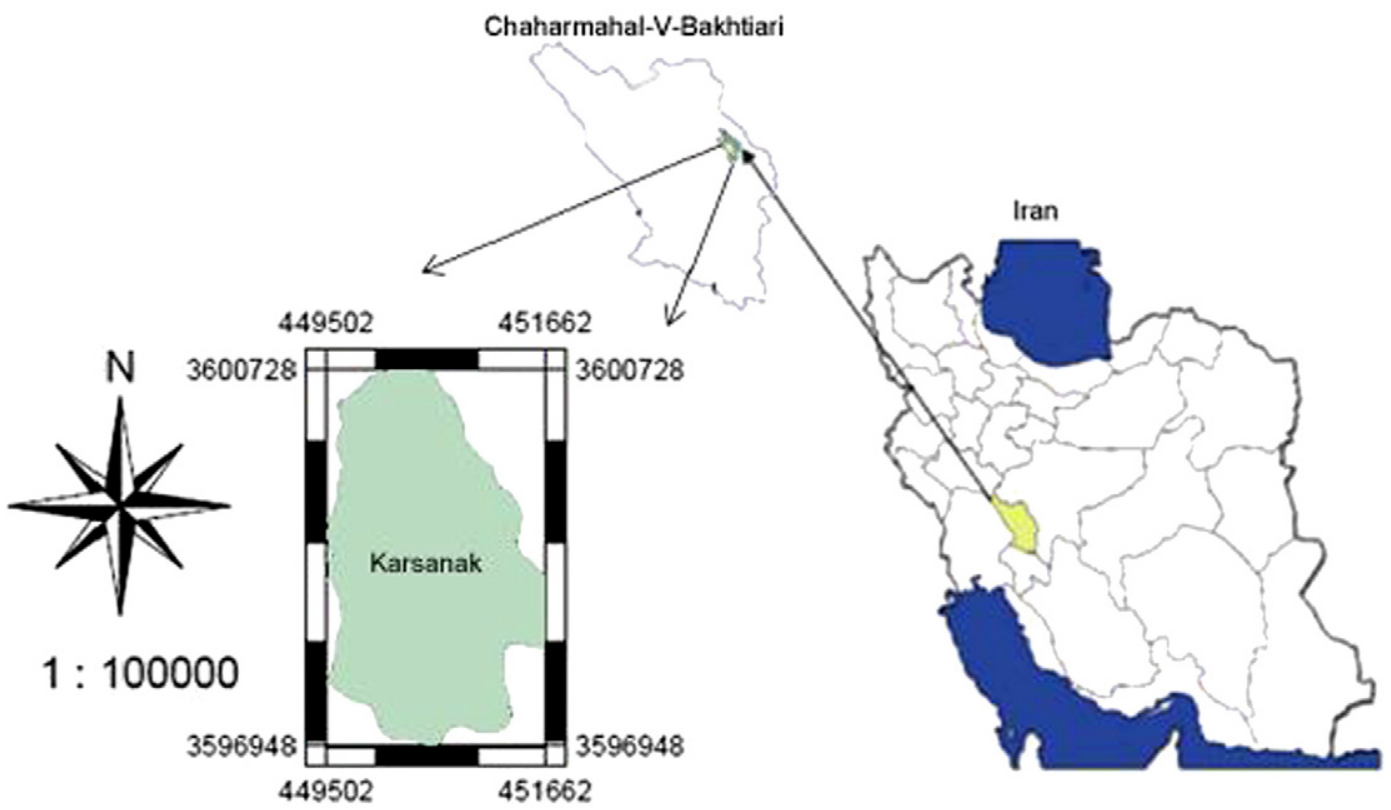

Figure 1. The location of the Karsanak rangelands, Chaharmahal-V-Bakhtiari province in Iran. 


\begin{tabular}{|c|c|c|c|c|c|c|c|c|}
\hline $\begin{array}{l}\text { Scientific } \\
\text { name }\end{array}$ & Code & $\begin{array}{l}\text { Life } \\
\text { form }\end{array}$ & Duration & Row & $\begin{array}{l}\text { Scientific } \\
\text { name }\end{array}$ & Code & $\begin{array}{l}\text { Life } \\
\text { form }\end{array}$ & Duration \\
\hline $\begin{array}{l}\text { Agropyron } \\
\text { intermedium }\end{array}$ & Agr int & $\mathrm{G}$ & $P$ & 15 & $\begin{array}{l}\text { Centaurea } \\
\text { virgate }\end{array}$ & Cen vir & $F$ & $P$ \\
\hline $\begin{array}{l}\text { Poa } \\
\text { bulbosa }\end{array}$ & Poa bul & $\mathrm{G}$ & $P$ & 16 & $\begin{array}{l}\text { Phlomis } \\
\text { olivieri }\end{array}$ & Phe oli & $\mathrm{F}$ & $P$ \\
\hline $\begin{array}{l}\text { Bromus } \\
\text { tomentellus }\end{array}$ & Bro tom & G & $P$ & 17 & $\begin{array}{l}\text { Achillea } \\
\text { santolina }\end{array}$ & Ach san & $\mathrm{F}$ & $P$ \\
\hline $\begin{array}{l}\text { Bromus } \\
\text { tectorum }\end{array}$ & Bro tec & G & A & 18 & $\begin{array}{l}\text { Taraxacum } \\
\text { montanum }\end{array}$ & Tarmon & $\mathrm{F}$ & $P$ \\
\hline $\begin{array}{l}\text { Stipa } \\
\quad \text { hohenackeriana }\end{array}$ & Sti hoh & $\mathrm{G}$ & $P$ & 19 & $\begin{array}{l}\text { Phlomis } \\
\text { persica }\end{array}$ & Phe per & $\mathrm{F}$ & $P$ \\
\hline $\begin{array}{l}\text { Melica } \\
\text { Persica }\end{array}$ & Mel per & $\mathrm{G}$ & $P$ & 20 & $\begin{array}{l}\text { Tanacetum } \\
\text { polycephalum }\end{array}$ & Tan pol & $F$ & $P$ \\
\hline $\begin{array}{l}\text { Heteranthelium } \\
\text { pilferum }\end{array}$ & Het pil & $\mathrm{G}$ & A & 21 & $\begin{array}{l}\text { Cousinia } \\
\text { bachtiarica }\end{array}$ & Cou bak & $F$ & $P$ \\
\hline $\begin{array}{l}\text { Astragalus } \\
\text { effusus }\end{array}$ & Ast eff & $F$ & $P$ & 22 & $\begin{array}{l}\text { Tragopogon } \\
\text { longirostris }\end{array}$ & Tra lon & $\mathrm{F}$ & $P$ \\
\hline $\begin{array}{l}\text { Eryngium } \\
\text { billardieri }\end{array}$ & Ety bil & $F$ & $P$ & 23 & $\begin{array}{l}\text { Cardaria } \\
\text { draba }\end{array}$ & Car dra & $\mathrm{F}$ & $P$ \\
\hline Euphorbia sp. & Eup sp. & $F$ & $P$ & 24 & $\begin{array}{l}\text { Stachys } \\
\text { inflata }\end{array}$ & Sta inf & $F$ & $P$ \\
\hline $\begin{array}{c}\text { Scorzonera } \\
\text { seidlitzia }\end{array}$ & Sco sed & $F$ & $P$ & 25 & $\begin{array}{l}\text { Astragalus } \\
\text { cunvirosteris }\end{array}$ & Ast Cur & $\mathrm{F}$ & $P$ \\
\hline $\begin{array}{l}\text { Scariola } \\
\text { orientalis }\end{array}$ & Sca ori & $F$ & $P$ & 26 & $\begin{array}{l}\text { Astragalus } \\
\text { verus }\end{array}$ & Ast ver & Sh & $P$ \\
\hline $\begin{array}{l}\text { Stachys } \\
\text { lavandulifolia }\end{array}$ & Sta lav & $F$ & $P$ & 27 & $\begin{array}{l}\text { Astregalus } \\
\text { adscendens }\end{array}$ & Ast ads & Sh & $P$ \\
\hline $\begin{array}{l}\text { Stachys } \\
\text { pilfera }\end{array}$ & Sta pil & $F$ & $P$ & & & & & \\
\hline
\end{tabular}

\section{G, grass; F, forb; Sh, shrub. $P$, perennial; A, annual.}

composition of the study area consists of a mixture of grasses, forbs, and shrubs, among which 27 species were dominant (Table 1).

\section{Grazing Time}

We determined the species composition of the diet of livestock grazing on the rangeland by measuring the duration of grazing on each species for sheep and goats, using chronometric and filming separately. For this purpose, according to Altman's instructions, ${ }^{8}$ we randomly selected the sheep and goats in the study area (provided that the selected livestock represented the age, size, and race of the herd). After ensuring that there was no change in the grazing behavior of the livestock in the vicinity, using chronometric and filming, we measured the duration of grazing by sheep and goats for each plant species. The duration of observations using chronometric and filming methods was 2 hours per day ( 1 hour in the morning and 1 hour in the afternoon) during the mature stage of plant growth and during a variety of times from early to late spring (the growth season in this site). Five forb species, three grass species, and one shrub species were considered the most commonly used forage by the sheep and goats in the study area. The main forbs included white eryngo or sea holly (Eryngium billardieri), black salsify (Scorzonera seidlitzii), santolina yarrow (Achillea santolina), rantavoikukat (Taraxacum montanum), and alfalfa (Medicago sativa). Dominant grasses were brome grass (Bromus tomentellus), intermediate wheatgrass (Agropyron intermedium), and bulbous bluegrass (Poa bulbosa). The main shrub species included gum dragon or tragacanth (Astragalus verus).

These species dominated the diets of both sheep and goats, but in different ratios (Fig. 2). Although the maximum 
selection index was obtained for alfalfa in the diets of both sheep and goats, its share in the diet of sheep was more than in that of goats. In general, among these plants, grasses were a smaller component in the diets of both sheep and goats. While most grasses were grazed in the same proportions by sheep and goats, sheep preferred brome, whereas goats preferred bulbous bluegrass. Of the forbs, alfalfa, black salsify, santolina yarrow, and rantoavoikukat were selected by goats to a significantly greater degree than by sheep. Goats also preferred the two spiny shrubs, namely, gum dragon and eryngo. The results of our study are in line with the results obtained by Borchard et al. ${ }^{9}$ who showed that sheep and goats usually graze forbs and shrubs, respectively, although species composition affect plant palatability and diet selection by sheep and goats. ${ }^{10}$ The green and edible plant parts of the nine species were clipped to ground level and stored in separate paper bags, and the clipped plant parts were air dried. After determining species composition of the livestock diet and the study area, to compensate for the effect of having a high or low share of each species in the diet selection, a selection index was calculated by using the formula given by Vallentine. ${ }^{11}$

\section{Physical Analysis}

With regard to physical (external) attributes, first, the most important plant external attributes influencing plant palatability were identified by using the values described in the literature, including succulence, leaf position, branch density, leaf trichome, leaf spininess, stem spininess, height, leaf/stem ratio, prehensile resistance, stem trichome, inflorescence spininess, and awns. After identifying the most important morphologic traits, we determined the quantity of these characteristics by using the plants database of the United States ${ }^{12}$ the BiolFlor database of Germany, ${ }^{13}$ and Ghahreman colored flora books. ${ }^{14}$ To do so, all the morphologic traits of plants based on the information given in these references (which contain the classification of the plants' morphologic traits) were elicited.

\section{Chemical Analysis}

For chemical analysis (forage quality and secondary compounds), we collected the edible and green parts of these plants during the mature stage of plant growth. Three replicated fresh samples from the current year's growth of these species were cut and properly stored in paper bags. The plant samples were air-dried in the paper bags and then stored for further analysis.

The nitrogen $(\mathrm{N})$ content of forage species was measured by using the micro Kjeldahl method. ${ }^{15}$ Next, CP was calculated by using Walton's formula. ${ }^{16} \mathrm{ADF}$ was determined by using the procedure described by Van Soest, ${ }^{17}$ and DMD was estimated by using the formula developed by Oddy et al. ${ }^{18}$ ME was estimated by using the equation recommended by the Association of Analytical Chemists ${ }^{15}$ (Table 2).

We used gas chromatography coupled with mass spectrometry (GC-MS) to determine the secondary compounds of the extracted dominant species. GC analyses were carried out using an Agilent $6890 \mathrm{~N}$ (Agilent, Waldbronn, Germany) gas chromatograph coupled with an Agilent 5973 quadrupole selective MS equipped with an inert ion source and provided with a split-splitless injection port and a $4.0 \mathrm{~mm}$ inner diameter (i.d.) liner. The MS was operated using electron impact mode $(70 \mathrm{eV})$. The helium carrier gas was maintained at a constant flow of $1 \mathrm{~mL} / \mathrm{min}$. An HP-5MS (5\% diphenyl-95\% dimethylpolysiloxane; Agilent) capillary column (30 $\mathrm{m} \times 0.25 \mathrm{~mm}$ i.d., $0.25 \mu \mathrm{m}$ film thickness) was used. Pulsed splitless (20 psi) injections $(4 \mu \mathrm{L})$ were performed with a 7683 automatic injector (Agilent) operating at $325^{\circ} \mathrm{C}$. Autosampler vials of $2-\mathrm{mL}$ capacity provided with $200-\mu \mathrm{L}$ microinserts with polymeric feet were used. The GC temperature was programmed as follows: start temperature $50^{\circ} \mathrm{C}$ (hold for 0.5 minutes), increase to $240^{\circ} \mathrm{C}$ at $15^{\circ} \mathrm{C} \mathrm{min}{ }^{-1}$ and hold for 3 minutes, increase to 300 at $10^{\circ} \mathrm{C} \min ^{-1}$ and hold for 3 minutes. The analytes were eluted with retention times of between 10 and 41 minutes, corresponding to acenaphthene (ACE) and Indeno[1,2,3-cd]pyrene (IND), respectively. The temperatures of the ion source and the transfer line were $220^{\circ} \mathrm{C}$ and $290^{\circ} \mathrm{C}$, respectively. The compounds were quantified in the selected ion monitoring

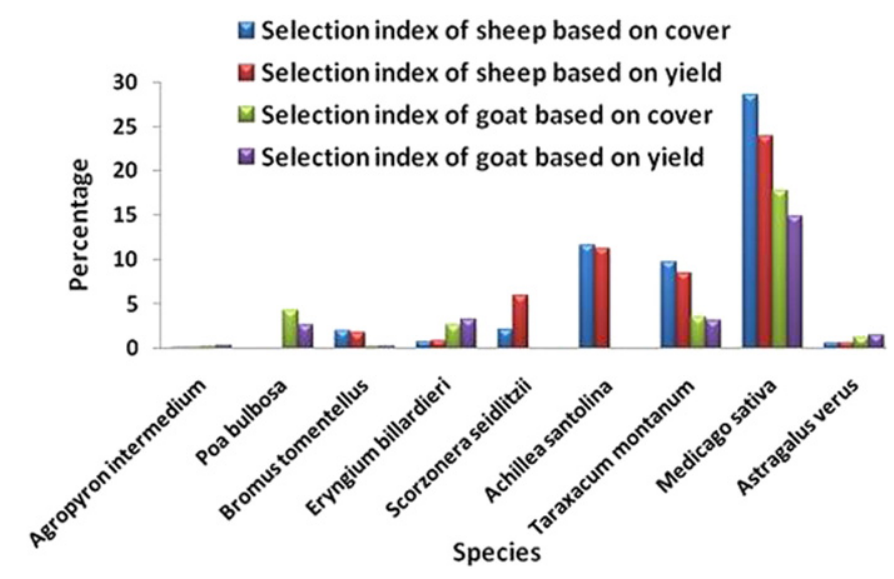

Figure 2. Selection index of plant species by sheep and goats based on the yield and cover of species in the regional plant composition. 
mode to improve the detection limits by using different ions. The identification of the compounds was confirmed by injection of pure standards and comparison of the retention time and full MS spectra. ${ }^{19}$ The chemical compounds determined by GC-MS were identified by using the formula developed by Adam $^{20}$ (Table 2).

Since the morphologic traits (external attributes), forage quality indicators ( $\mathrm{CP}, \mathrm{ADF}, \mathrm{DMD}$, and $\mathrm{ME}$ ), and the identified secondary compounds of plants involve many factors and understanding the relationships between them and plant palatability is a complex task, we used principal component analysis (PCA) to reduce the number of indicator dimensions. PCA is a data-driven modeling technique, which transforms a set of correlated variables into a smaller set of new variables (principal components) that are uncorrelated and retain most of the original information. A reduced-dimension PCA model is useful to detect and diagnose abnormalities in the original system in a robust way. ${ }^{21} \mathrm{We}$ conducted a PCA to find the eigenvalue and eigenvector of the physical (external attributes) and chemical characteristics (forage quality and secondary compounds). For this purpose, the sampled plants were ranked on the basis of these indicators by using PC-ORD software, version 7.0 (MjM Software, Gleneden Beach, OR). ${ }^{22}$ Then, the quantitative values for eigenvalue and eigenvectors of the plant species indicators (external attributes, forage quality, and identified secondary compounds) were plotted on the main axis of the PCA. Pearson correlation coefficient was applied to find the association between the selection index and physical and chemical characteristics.

We found a significant relation between the selection index of the species by sheep with the first and third axes of the PCA (based on cover and yield), but not for goats (Table 3). According the first axis of Figure 3, the compounds of "campholenal < alpha $>$," "carvyl acetate < cis $>$," "caryophylla-4 (14), 8 (15)-dien-5.alpha-ol," "cineole <1.8>," "dill ether," and "isoborneol" had the highest effect on plant palatability for the sheep. These compounds are followed by other important compounds and characteristics, including "decadienal <2E, 4E >," "octanone <n>," "mean of DMD," "mean of ME," mean of ADF," "height," "leaf spininess," "spathulenol," and "globulol," had the highest eigenvalues in the third axis, respectively.

\section{Discussion}

We found that the livestock type has a noticeable effect on plant palatability, and this has been reported in previous studies. 11,7,23 The species were grazed by goats, based on the yield and canopy cover. Accordingly, we concluded that goats are less selective compared with sheep because they do not graze plants on the basis of physical and chemical characteristics but on the frequency of the plants in the field. Sheep, in contrast, are more selective because they graze plants mainly on the basis of their physical and chemical characteristics (Table 3). We can conclude that the effect of livestock type on rangelands is significant. In other words, the palatability of rangeland species could vary, depending on the livestock type, and optimal grazing can be achieved by the common grazing of goats and sheep as a result of the differing grazing times of plant life forms and plant species. According to various researchers, using more than one type of livestock is essential for reaching maximum production, increasing range efficiency, rangelands improvement, increasing grazing capacity in the long term, increasing livestock productions, and increasing species diversity and income diversity. ${ }^{24}$ This result is largely consistent with other studies. ${ }^{7}$

Although many studies on the relationship between morphologic and chemical characteristics of the species' palatability and diet selection have been conducted, ${ }^{2,3,7}$ the relationship between palatability and all these characteristics has rarely been investigated inclusively. Our current study addressed the association of both the morphologic (physical) characteristics of plants and their chemical compounds to palatability, as mentioned by Fomum et al. ${ }^{2}$ and Mkhize et al. ${ }^{3}$ who believed that livestock graze the species on the basis of the physical and chemical traits of plants during the grazing season.

Table 2. The list of formulae used in the study and their sources

\begin{tabular}{|c|c|}
\hline$\% C P=\% N æ 6.2$ & Walton $(1983)^{16}$ \\
\hline$\% D M D=83.58 \quad 0.824 A D F \%+2.626 \mathrm{~N} \%$ & Oddy et al. $(1983)^{18}$ \\
\hline${ }^{*} M E=0.17 D M D \% 2$ & AOAC $(1990)^{15}$ \\
\hline${ }^{\dagger} K I=100 N\left(R T_{s} R T_{n}\right) /\left(R T_{n+1} \quad R T_{n}\right)$ & Adams $(2004)^{20}$ \\
\hline$\ddagger S I=A / B$ & Vallentine $(2001)^{11}$ \\
\hline \multicolumn{2}{|c|}{$\begin{array}{l}\text { * ME/DM is the ME in mega joules (MJ) per kilogram (kg) of feed DM. } \\
\text { KI is the Kovats index of each chemical composition, } \mathrm{N} \text { is the number of the closest small spectrum to the } \\
\text { spectrum composition, RTs is the retention time of the spectrum sample, RTn is the retention time of the lowest } \\
\text { spectrum close to the spectrum sample, and RTn+1 is the retention time of the highest spectrum close to the } \\
\text { spectrum sample. } \\
\text { SI is the selection index of each species, A is the average presence of a species in the diet of livestock (sheep } \\
\text { or goat), and B is the presence of a species in the total plant composition of the rangeland. }\end{array}$} \\
\hline
\end{tabular}


Table 3. Results of the correlation test between the first and fourth principal component analysis (PCA) axes for external attributes, forage quality, and plant secondary compounds for each dominant species in the composition of plant species and the selection index of species by sheep and goats in Karsanak rangelands of Chaharmahal-V-Bakhtiari Province

\begin{tabular}{|c|c|c|c|c|c|c|}
\hline Axis & $\begin{array}{l}\text { Statistic } \\
\text { indices }\end{array}$ & $\begin{array}{l}\text { Selection } \\
\text { index of goats, } \\
\text { based on yield }\end{array}$ & $\begin{array}{l}\text { Selection } \\
\text { index of sheep, } \\
\text { based on cover }\end{array}$ & $\begin{array}{l}\text { Selection } \\
\text { index of sheep, } \\
\text { based on yield }\end{array}$ & $\begin{array}{l}\text { Selection } \\
\text { index of goats, } \\
\text { based on cover }\end{array}$ & $\begin{array}{l}\text { Selection } \\
\text { index of goats, } \\
\text { based on yield }\end{array}$ \\
\hline \multirow[t]{3}{*}{$\begin{array}{c}\text { Axis } \\
1\end{array}$} & $\begin{array}{l}\text { Pearson } \\
\text { correlation }\end{array}$ & 0.226 & $0.650^{*}$ & $0.650^{*}$ & 0.092 & 0.226 \\
\hline & $\begin{array}{l}\text { Significance } \\
\text { level (bilateral) }\end{array}$ & 0.279 & 0.029 & 0.029 & 0.407 & 0.279 \\
\hline & Number & 9 & 9 & 9 & 9 & 9 \\
\hline \multirow[t]{3}{*}{$\begin{array}{c}\text { Axis } \\
3\end{array}$} & $\begin{array}{l}\text { Pearson } \\
\text { correlation }\end{array}$ & 0.117 & $0.583^{*}$ & $0.583^{*}$ & 0.285 & 0.117 \\
\hline & $\begin{array}{l}\text { Significance } \\
\text { level (bilateral) }\end{array}$ & 0.382 & 0.05 & 0.05 & 0.229 & 0.382 \\
\hline & Number & 9 & 9 & 9 & 9 & 9 \\
\hline
\end{tabular}

Our results indicate that when both the physical and chemical characteristics of plants are used, the results more accurately explain characteristics such as rangeland species' palatability and the diet selection of livestock (Table 3). Rangeland species' palatability and the diet selection of livestock are related to a set of factors. For example, if the palatability of gum dragon, rantavoikukat, and alfalfa was investigated only on the basis of a single factor (external attributes, forage quality, or plants' secondary compounds alone), they would have not been deemed palatable for grazing because each of these species is not suitable for grazing with respect to at least one trait (e.g., with regard to external attributes and secondary compounds). However, when the palatability of these plants are investigated using both physical characteristics and chemical compounds, the species are deemed palatable. Our results confirm public opinion about the palatability of these species and that the rangeland species' palatability is a multifactorial feature resulting from the chemical and physical characteristics of plant species. ${ }^{2,3,7,25}$

Similar points can be raised regarding the other plant species investigated (white eryngo, black salsify, santolina yarrow, brome grass, intermediate wheatgrass and bulbous bluegrass.). Each, if judged on a single attribute, would be considered unsuitable for grazing. But in practice, these plants

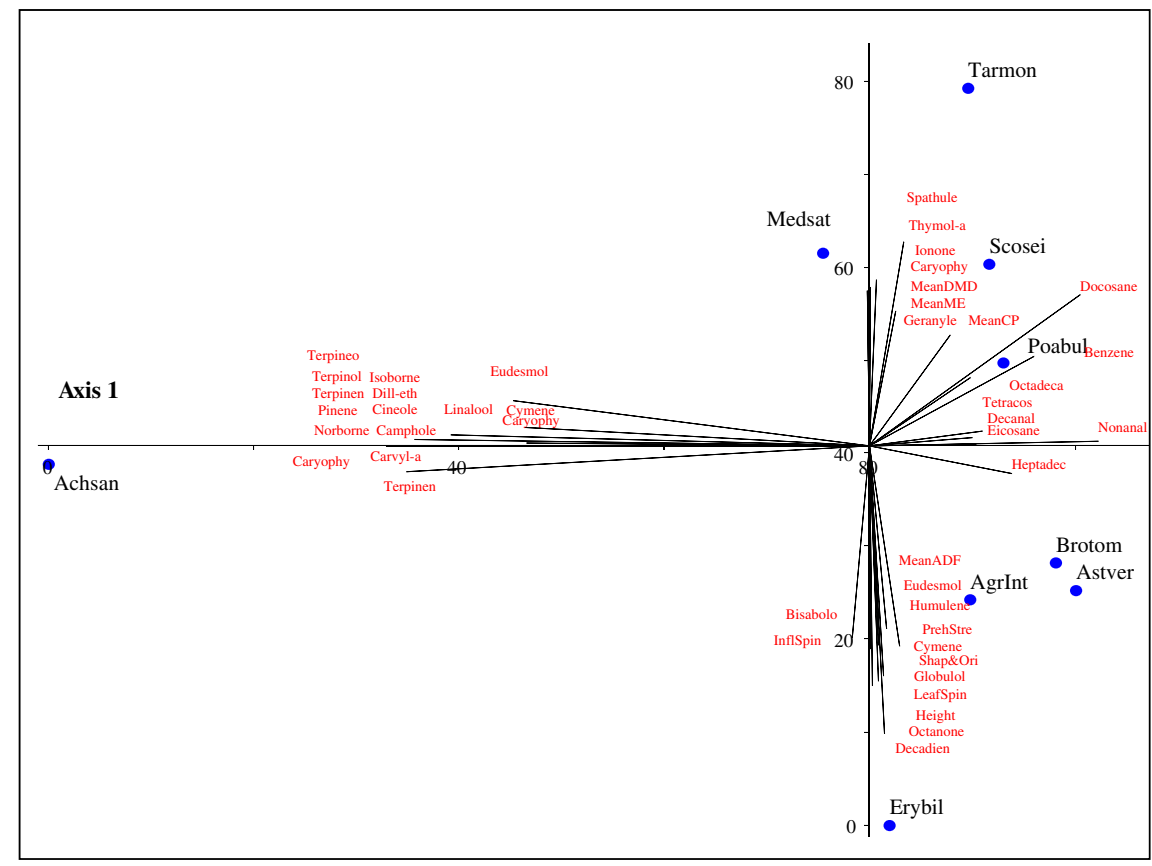

Figure 3. The eigenvalues for external attributes forage quality and plant secondary compounds in a two-dimensional space between the first and third principal component analysis (PCA) axes. (For the abbreviations of plant names, refer to Table 1, and for the abbreviations of plant characteristics, refer to Table 3.) 
have the highest palatability among the many species in the Karsanak rangelands, mainly because of the interaction of several factors. For instance, eryngo and gum dragon are suitable for grazing because of their forage quality and secondary compounds. Black salsify, santolina yarrow, and rantavoikukat are suitable for grazing because of their external attributes and forage quality. Forage quality and secondary compounds should then be considered as important indicators when determining rangeland plant palatability. Accordingly, we may want to spend more effort determining rangeland plant forage quality and secondary compounds. For example, these characteristics for all rangeland species in a variety of seasons and regions could be evaluated to determine plant palatability. Also, intermediate wheatgrass, brome, and bulbous bluegrass are suitable for grazing because of their external attributes, and since external plant attributes are constant in different regions and are easily detectable, these traits can also be used for ranking plant palatability.

We detected the physical attributes of leaf spininess, prehensile resistance, stem spininess, inflorescence spininess, and height strongly influence plant palatability. The results of our study are similar to the results obtained by Heady ${ }^{1}$ Vallentine $^{11}$ Borchard et $_{\text {al. }}{ }^{9}$ and Mouissie et al. ${ }^{26}$ who showed that external attributes, such as awns, spines, hairiness, and position of leaves, stickiness, and texture, the proportion of leaves, stems, and fruits, have been related to palatability. Since leaf spininess, stem spininess, inflorescence spininess, and branch density had the lowest eigenvalue, these traits have negative effects on plant palatability, ${ }^{1-3,7,11}$ whereas height, succulence, leaf position, and leaf/stem ratio with the highest eigenvalues positively affect plant palatability. In line with these results, Mkhize et al. ${ }^{3}$ observed that plant physical factors, such as spinescence, leaf type, and shoot morphology, markedly influenced intake. As a result, developing species with suitable physical attributes, such as suitable height, succulence, leaf position, and leaf/stem ratio should be one of the objectives in future grass genetics research to improve the palatability of the species in rangelands. ${ }^{7}$

We also found DMD, ME, and ADF are some of the most important chemical compounds that influence plant palatability, as noted by Bagherirad et al. ${ }^{27}$ who believed that livestock graze the species with protein and energy levels that exceeded "good" with regard to the requirements during the hot summer months (see Fig. 3). Secondary compounds, including "campholenal <alpha>," "carvyl acetate < cis>," "caryophylla-4 (14), 8 (15)-dien-5.alpha-ol," "cineole < 1.8>," "dill ether," "isoborneol," "decadienal $<2 \mathrm{E}, 4 \mathrm{E}>$," "octanone $<\mathrm{n}>$," "spathulenol," and "globulol," had the highest effect on plant palatability. Our results are in line with the results obtained by Elger and Barrat-Segretain, ${ }^{4}$ who showed high correlations between secondary compounds and plant palatability. Perhaps more significant than the amount of any chemical compound is the combination of components. ${ }^{1-3}$ Although of all chemical ingredients, protein shows the best correlation to livestock preference for forages, several investigators believe that the total of the chemical compounds of a plant is a better indicator of palatability. ${ }^{7,27}$ Baraza et al. ${ }^{28}$ and Sebata and Ndlovu ${ }^{29}$ observed similar results for domestic livestock in the Mediterranean mountain forest of Spain and in the semi-arid savannas, respectively.

In summary, we concluded that the three indicators-plant external attributes, forage quality, and secondary compounds - should be used together for determining rangeland plant palatability and developing methods such as PCA, which we presented here. PCA is an effective technique to determine rangeland species palatability and can help rank rangeland plant palatability correctly, often with less time and cost. Finally, according to our results, if taking the three indicators into account is not feasible because of labor intensity or the cost of determining the secondary compounds, at least, two main indicators, that is, plant external attributes and forage quality, should be used for plant palatability classification. However, given that our study was carried out in one season (spring) and at a single, small site, it must be kept in mind that plant palatability may change, with seasonal variations and plant growth stage, at least in perennial plants, with younger plants, and with temperature and water availability, which could induce larger shifts in the relative palatability of species. Accordingly, our study should be repeated in other seasons to confirm the results. Also, further investigations at other sites are required before generalizing these results from the Karsanak rangeland to other regions.

\section{Management Implications}

Rangelands and livestock production on rangelands have historically been at the center of farming and agriculture in many countries, especially in Iranian society, economy, and culture. Rangeland species, especially grasses (e.g., Bromus spp. and Agropyron spp.) forbs (e.g., Achillea spp.), and shrubs (e.g., Astragalus spp.), are the most available forage species in the Karsanak rangelands and have been considered the main diet of sheep and goats, the main livestock on Iranian rangelands. ${ }^{7}$ Determining palatability of these species on the basis of their chemical and physical traits is necessary for protecting rangelands species if sustainable rangeland management is the goal. Knowledge of rangeland species palatability is vital for estimating rangeland grazing capacity. Better understanding of palatability will, in turn, lead to better understanding of the grazing behavior of herbivores and vegetation changes resulting from differentiated habitat use and will enable managers to better formulate animal management practices, plan vegetation improvement programs, and determine expectable food intake. ${ }^{1}$ Grazers can noticeably reduce the vigor of palatable species. Biomass losses at the mature stage can decrease seed production and vegetative extension, and differential grazing can consequently alter the dominance of plant species. Plant palatability thus becomes a key ecologic trait, and it may not be surprising that the most palatable species are generally restricted to habitats with low pressure from herbivore presence. The results of such studies can create a useful tool for decision makers, practitioners, and rangeland users whose main concern is unsustainable rangeland ecosystems. 


\section{Acknowledgment}

The authors wish to thank Mr. Nji Tizi Clauvis Taning for his kind help with the English language editing of this paper.

\section{References}

1. Heady, H.F. 1964. Palatability of herbage and animal preference. J Range Manag 17(2):76-82.

2. Fomum, S.W., P.F. Scogings, L. Dziba, and I.V. Nsahlai. 2015. Seasonal variations in diet selection of Nguni goats: effects of physical and chemical traits of browse. Afr J Range Forage Sci 32(3):193-201.

3. Mkhize, N.R., P.F. Scogings, I.V. Nsahlai, and L.E. Dziba. 2014. Diet selection of goats depends on season: roles of plant physical and chemical traits. Afr J Range Forage Sci 31(3):209-214.

4. Elger, A., And M.H. Barrat-Segretain. 2004. Plant palatability can be inferred from a single-date feeding trial. Funct Ecol 18:483-488.

5. Azadi, H., J. Vanden Berg, M. Shahvali, and G. Hosseininia. 2009. Sustainable rangeland management using fuzzy Logic: a case study in Southwest Iran. Agric Ecosyst Environ 131(3\&4):193-200.

6. Koc, A., W.H. Schachtb, and H.I. Erkovan. 2015. The History and Current Direction of Rangeland Management in Turkey. Rangelands 37(1):39-46.

7. Raufirad, V., A. Ebrahimi, and H. Azadi. 2015. Animal preference and external plant attributes: application of principle component analysis. J Biodivers Environ Sci 6(1):22-33.

8. Altmann, J. 1974. Observational study of behavior: sampling methods. Behavior 49:227-267.

9. Borchard, F., J.H. Berger, M. Bunzel-DrüKe, and T. Fartmann. 2011. Diversity of plant-animal interactions: possibilities for a new plant defense indicator value? Ecol Indic 11:1311-1318.

10. Bork, E.W., AND B.D. Inving. 2015. Seasonal availability of cool- and warm-season herbage in the northern mixed prairie. Rangelands 37(5):178-185.

11. Vallentine, J.F. 2001. Grazing management. 2nd ed. San Diego, CA: Academic Press [675 pp.].

12. USDA-NRCS, 2009. The plants database. Baton Rouge, LA: National Plant Data Center. 70874-4490 USA. Available at: http://plants.usda.gov. Accessed 17 September 2009.

13. UFZ, AND ISSG, 2009. Vascular Plants Database and Information System Search Germany. Available at: http://www.ufz.de/biolflor/ index.jsp 2009 Accessed 17 September 2009.

14. Ghahreman, A. 1986. Colorful Iranian flora. Research Institute of Forests and Rangelands, vol. 1-28. in Persian.

15. Association of Analytical Chemists, 1990. Official methods of analysis. 15th ed. Washington, D.C.: AOAC. 746 pp.

16. Walton, P.D. 1983. Production and management of cultivated forages. Reston, VA: Prentice-Hall Company. 336 pp.

17. Van Soest, P.J. 1963. Nutritional ecology of the ruminant. Corvallis, OR: O \& B Books. 373 pp.

18. Oddy, V.U., G.F. Robards, And S.G. Low. 1983. Prediction of in-vive dry matter digestibility from the fiber and nitrogen content of a feed. In: Robards GE, \& Packhman RG, editors. Feed information and animal. Australia: Common wealth Agricultural Bureux. [295-298 pp.].

19. Cacho, J.I., N. Campillo, P. Vinas, and M. HernandezCordobA. 2016. Evaluation of the contamination of spirits by polycyclic aromatic hydrocarbons using ultrasound-assisted emulsification microextraction coupled to gas chromatography-mass spectrometry. Food Chem 190:324-330.

20. AdAMs, R.P. 2004. Identification of essential oil components by chromatography/quadrupole mass spectroscopy. San Diego, CA: Academic Press [875 pp.].

21. Schweizer, K., P.H. Cattin, C. Brunner, R. Muller, B. Huber, And C. Romkes. 2012. Automatic selection of a representative trial from multiple measurements using principle component analysis. J Biomech 45:2306-2309.

22. McCune, B., And M.J. Mefford. 1999. PC-ORD for Windows: multivariate analysis for ecological data. Version 7.0. Gleneden Beach, OR: MjM Software.

23. Bagheri, H., M. Adnani, And A. Tavili. 2007. Studying the relationship between livestock and plant composition (Case study: semi-Steppic ranges of Vesf-Qom province). Ir $J$ Res Constr 74(1):155-162.

24. Czech, B., R. Heitschmidt, J. Brown, and A. Hild. 2015. Sustainable rangeland management, economic growth, and a cautious role for the SRM. Rangelands 30(6):33-37.

25. Arzani, H. 2009. Forage quality and daily requirement of grazing animal. Teheran, Iran: University of Tehran Press.

26. Mouissie, A.M., M.E.F. Apol, G.W. Heil, and R.V. Diggelen. 2008. Creation and preservation of vegetation patterns by grazing. Ecol Model 218:60-72.

27. Bagherirad, E., M. Mesdaghi, N. Ahmad, and M. Abdullah. 2015. Nutritional quality and quantity of available forages relative to demand: a case study of the goitered gazelles of the Golestan National Park, Iran. Rangelands 37(2):68-80.

28. Baraza, E., J.A. Hodar, And R. Zamora. 2009. Consequences of plant chemical diversity on domestic goat food preference in Mediterranean forest. Acta Oecol 35:117-127.

29. Sebata, A., And L.R. Ndlovu. 2012. Effect of shoot morphology on browse selection by free ranging goats in a semi-arid savanna. Livest Sci 44:96-102.

Authors are Ph.D. Student in Range Management, Department of Natural Resources, Sari University of Agricultural Sciences and Natural Resources, Sari, Iran (Raufirad, al.raufi@yahoo.com); Senior Researcher, Department of Geography, Ghent University, Belgium, Centre for Environmental Sciences, Hasselt University, Diepenbeek, Belgium, Economics and Rural Development, Gembloux Agro-Bio Tech, University of Liege, Belgium (Azadi); Associate Professor, Department of Natural Resources, Shabrekord University, Iran (Ebrabimi); and Ph.D. Student in Range Management, Department of Natural resources, Sari University of Agricultural sciences and Natural Resources, Sari, Iran (Bagheri). 